\title{
Stakeholders Opinions of Health-Related Conditions of Female Head Porters in Kumasi/Asokore Mampong
}

\author{
Justice Ofori-Amoah $^{1 *}$, A, Justice Thomas Sevegu ${ }^{2}$, B, Sheila Ofori-Addai ${ }^{3}$, C. Michael \\ Rockson Adjei ${ }^{4}$ \\ ${ }^{1}$ Department of Public Health, Texila American University, Ghana \\ ${ }^{2}$ Municipal Health Directorate, Atwima Nwabiagya, Nkawie, Ghana \\ ${ }^{3}$ Municipal Health Directorate, Ejisu, Ashanti-Ghana \\ ${ }^{4}$ Regional Health Directorate, Ghana Health Service, Kumasi, Ghana
}

\begin{abstract}
Young females usually migrate from the Northern part of Ghana to the South to engage in head porting business. However, the high cost of rent in urban areas and the poor environmental conditions of poor urbanites have exposed head porters to bad conditions with varying implications on health and well-being. This study examines the health-related conditions of female head porters in Kumasi through stakeholders' opinions. The study used quantitative methods in eliciting information from female head-porters in Asokore Mampong, Kumasi. In all, 100 respondents; comprising relatives of female head porters and other opinion leaders such as the Assembly member, Imam, Pastor, Teachers from Northern Ghana, were interviewed through self-administered questionnaires. Data were analyzed using a statistical package for the social sciences (SPSS) and excel. Economic reasons remain topical for the migration of females from the north to the south to engage in head porting. While many of these migrants do not return home, leading to the emergence of migrant settlements in Kumasi, others return to support their families with their earnings. Stakeholders argued that skills development and creating of entrepreneurial ventures are necessary to reduce the northsouth migratory patterns. The migration of females from the north to the south in search of greener pastures is likely to continue as a result of opportunity gaps. However, worsening conditions of living may deteriorate the health conditions of some of the migrants. Stakeholders recommend a new wave of solutions with focus on skills development, job creation, and entrepreneurial training as solutions.
\end{abstract}

Keywords: Female migrants, Health seeking, Head porters, Migration, Stakeholders.

\section{Introduction}

Globally, economic issues have been the trending factor that affects migration despite the possibility of a complex mix of factors. With about $30 \%$ of Ghanaians living below the poverty line [1], measures to achieve economic stability become expedient. In order to lift themselves out of the poverty brackets, rural women and girls usually migrate from the northern part of Ghana to the southern part to engage in head porting business popularly called "kayayo" [2].
The involvement of mostly women in head porting could be due to the fact that women from Ghana are used to head porting as they often carry goods from the farms to their homes and sometimes from the homes to the markets [3]. Irrespective of the proliferation of automobiles which has reduced the burden of women, most rural women still engage in head porting business as their main means of transport [4]. This makes it easy for these women to engage in head porting for economic gains when they later migrate to urban centers. 
Again, head porting becomes the most visible job since most of these migrants do not have the skills in order to engage in competitive urban businesses [5].

Women from the northern part of Ghana also depend on their husbands for almost every need of theirs [6]. As a result, their healthcare needs, feeding, clothing, entertainment, and other forms of needs are dictated by their husbands [7]. In divorce cases, the women are left with nothing other than to migrate down south to engage in head porting business. [8] has accused women's engagement in head porting to the limited control of family economic resources in Ghana and the northern region in particular. Though some of these young women and girls who migrate to engage in head porting end up an unwanted pregnancy due to rape, the quest for financial independence keeps them engaging in head porting [9].

Poor urban areas are believed to have one of the worst performances in morbidity, mortality, and poor environmental and associated health risk [10]. There are varying degrees of health needs and how they are met by these poor migrant communities [11]. Due to poor incomes and poor health-seeking behaviours, it could be due to the absence of health facilities for them, and the urban poor tend to suffer healthcare challenges than the rich [12]. Even though poor urbanites claim to be better off in urban areas than living in rural areas, poor environmental sanitation and unhygienic nature could lead to an outbreak of communicable diseases such as cholera, malaria, pneumonia among others [13]. This situation exposes the poor urbanites to health-related conditions with varying degrees of adaptability. Particularly, the female head porters who do not have decent accommodation in cities are exposed to healthrelated and environmental concerns [14].

Though there are contesting claims that the migrant head porters have better healthcare than their counterparts in rural areas, recent research in Bangladesh and Kenya proves otherwise as there are obvious trends of rural dwellers being better in health indicators than the poor urbanites $[15,16]$. Apart from the low-income levels that can deprive them of better healthcare, poor urbanites also face poor environmental and nutritional issues that make them vulnerable to diseases. The exposure of poor urbanites to environmental pollution, choked drains, slum areas, and generally poor environments could worsen their plight [17]. One thing that is fundamental to the development of better health conditions for the urban poor in general and female head porters in particular is stakeholder engagement to understand the socio-economic and cultural dynamics that shape the pursuance of head porting [18].

To understand the health-related conditions of poor migrant women and girls, there is a literature deficit in health-related conditions of head porters and stakeholder opinion. Though literature is inundated in health in general and science in particular, limited research exists in health-related conditions of female head porters and stakeholder opinion. Interestingly, most female head porters neither have permanent homes nor permanent jobs [12]. This makes it difficult to trace them for any comparisons. Nevertheless, the need for stakeholders' engagement on the motivating factors, pros and cons, and health-related conditions of female head porting is emerging. This will help to fully conceptualize how female porters move, work and live within the complex urban and cityscape [11, 14]. There are a number of reasons why people engage in head porting business in Accra and Kumasi. While the people who usually engage in this business remain young ladies from the northern sector of the country, the populations, in general, are varied and include all categories of people. Irrespective of the financial gains obtained from head porting, the activities of female head porters have varied implications for society and individuals at large. Problems such as lack of shelter, food, mental and physical health risks are associated with head porting [12]. In terms 
of mental well-being, female porters are prone to acculturative stress, a response by people to life events because of intercultural contact [19].

[1] indicates that some of these young porters are lured into prostitution or coerced into sexual favours to gain basic human needs. [12], an article in the Ghanaian newspaper "The Statesman" established that porters are exposed to reproductive and physical health risks. Female head porters live in unkempt environments in general with poor living and working conditions and vulnerable to sexually transmitted diseases, including HIV/AIDS [20].

Stakeholder opinions about the exposure and conditions of female head porters remain largely polarised. While some think that female head porters earn a living and income through their activity, others hold that the activities expose innocent young ladies to rapists and all forms of social vices. Literature posits that some female head porters are occasionally harassed by the police, drivers, and city guards [21]. Apart from occasions when the head porters are assaulted on the least mistake committed, Susu collectors (informal bankers) act as safe-keepers of head porters' money and abscond at times [20]. Family members who provide accommodation for the head porters have been known to spend money the porters give them for safekeeping without paying back [8]. However, literature on stakeholders' opinions of the activities of female head porters in urban space is scanty. This paper investigates the health-related conditions of female head porters and the opinions of stakeholders in Kumasi. Therefore, this study attempts to identify health-related challenges facing female head porters in Kumasi, assess the role of stakeholders in addressing the migration of females to Southern Ghana, and explore various mechanisms used by these female head porters in managing their health needs.

\section{Significance of the Study}

Stakeholder opinion on female head porting and the health-related activities of the same is important in shaping policy outcomes in containing internal migrations and tackling unemployment, especially in the middle class and uneducated class. The outcome of this study will also impact academia as one of the studies that combine the health-related conditions of the female head porters and stakeholders' opinions on head porting. It will lastly impact society on the impact of engagement in head porting activities and societal development. The comprehensive understanding of the discussions in this paper is important in shaping modern discourse in health, migration, and underserved sections of communities.

\section{Statement of Problem}

Due to the booming business environment and the centrality of Kumasi, it serves as a converging point for almost all works of life in business and industry. While Kumasi's market has received expansion over the last few decades, the influx of female head porters from the north and the health-related conditions of these group pose threat to the sustainability and development of the city [24]. This is because some of these female head porters lack accommodation, income, adequate meals, and generally poor living conditions. Some even find accommodation in corridors, verandas, squalors, and squatters [22].

While research has approached the issues of migration, conditions of head porters, and health-related conditions of poor neighbourhood's, research that comprehensively examines the health-related conditions of female head porters and stakeholder opinion on the activities of head porting is limited. This study, therefore, sought to investigate the health-related conditions and opinions of stakeholders on the activities of female head porters. This is important in other the shape understanding through the story of both the head porters and the stakeholders in understanding urban realities. 


\section{Materials and Methods}

\section{Research Design and Study Population}

This study used a quantitative method [23] to collect and analyze data on the health-related conditions of female head porters and stakeholders in Kumasi. The study population consist of female head porters and stakeholders in Kumasi. The interviews were conducted for 100 stakeholders, consisting of parents, chiefs, assembly members, traditional leaders and other benefactors of the head porters were interviewed.

\section{Ethical Consideration}

Ethical considerations are important in the content of research. For the ability to replicate the findings of the study, the methodology and all other logical frameworks that defines knowledge were well established. Also, ethical clearance was obtained from the Kwame Nkrumah University of Science and Technology and the Komfo Anokye Teaching Hospital. The instruments for data collection were attached as part of the required documents for evaluation by the ethics board. The ethics board approved the study before it was carried out.

\section{Sample Size Determination}

Sampling is important as it sometimes becomes almost impossible to deal with larger numbers in the conduct of studies [24, 25]. The study population for this research was the opinion leaders or stakeholders of female head porters in urban areas. Given how large this population could be, the study randomly selected 100 stakeholders and opinion leaders to respond to the questions. This was necessary as these stakeholders and opinion leaders contribute a lot to shaping policies aimed at improving the standard of living of head porters.

\section{Data Collection}

Data was collected from respondents through a self-administered questionnaire on the healthrelated conditions of female head porters and stakeholders' opinions in Kumasi. The nature of the questionnaire design included both openended and close-ended questions. The questions targeted the socio-economic and cultural characteristics of head porters, health-related conditions, and stakeholders' perceptions about the activities of head porters.

After filling the questionnaires, the responded sheets were collected, collated, and analyzed using descriptive statistics. Percentages, tables, means, and frequencies were used in describing the health-related conditions of female head porters and stakeholders' opinions. Inferential statistics were used in determining the relationship between the demographic characteristics and health-related conditions of head porters [6]. IBM SPSS 21 was used to analyze and interpret the data obtained from the field.

\section{Results}

\section{Demographic Characteristics}

This study examines the health-related conditions of female head porters and the stakeholders' opinions about the activities of female head porters in Kumasi. In total, the study interviewed 100 stakeholders and 250 female head porters in Kumasi. The mean age of the stakeholders interviewed was 44.10 $($ minimum $=28$, maximum $=70)$ with a deviation of 10.61. The female head porters' other hands, have a mean age of $25.06 \pm 7.06$. About $46 \%$ of the stakeholders interviewed had education up to the tertiary level. This was followed by those who have never had education (25\%), JHS and Primary school (24\%), and not educated 5\%. Again $45 \%$ of the stakeholders were married, $36 \%$ single, and 
19\% divorced. These socio-demographic characteristics described are important because they contribute to the larger debate in shaping and understanding the reasons why young females engage in head porting (Kayayie) and the possible measures to curb it. The proceeding sections describe the results of the study under specific headings. The following section presents the findings from the study.

Table 1. Occupational Status of Stakeholders

\begin{tabular}{|l|l|l|}
\hline Occupation of Stakeholders & Frequency & Percent \\
\hline Accountant & 2 & 2.0 \\
\hline Assembly man & 17 & 17.0 \\
\hline Businessman & 13 & 13.0 \\
\hline Carpenter & 9 & 9.0 \\
\hline Chief/Traditional leader & 19 & 19.0 \\
\hline Driver & 1 & 1.0 \\
\hline Farmer & 18 & 18.0 \\
\hline Nurse & 9 & 9.0 \\
\hline Secretory & 1 & 1.0 \\
\hline Security personal & 1 & 1.0 \\
\hline Teacher & 10 & 10.0 \\
\hline
\end{tabular}

Table 2. Common Health Conditions of Female Head Porters

\begin{tabular}{|l|l|l|}
\hline Variable & Frequency $(\mathbf{n = 1 0 0})$ & Percent $(\mathbf{\%})$ \\
\hline Malaria & & 38.0 \\
\hline General body pains & & 18.8 \\
\hline Typhoid fever & & 15.2 \\
\hline Boils & & 12.8 \\
\hline Gonorrhea & & 8.4 \\
\hline Wounds & & 6.4 \\
\hline Total & $\mathbf{1 0 0}$ & 100 \\
\hline
\end{tabular}

Table 3. Reasons for Involvement in Head Porting

\begin{tabular}{|l|l|l|}
\hline Variable & Frequency $(\mathbf{n}=\mathbf{1 0 0})$ & Percent (\%) \\
\hline Head about young women traveling for head porting \\
\hline No & 1 & 1.0 \\
\hline Yes & 99 & 99.0 \\
\hline Number of young women who move to the south \\
\hline Mean ( \pm SD) & $116.71 \pm 67.96$ & \\
\hline$<50$ & 18 & 18.0 \\
\hline $50-99$ & 15 & 15.0 \\
\hline $100-199$ & 41 & 41.0 \\
\hline $200+$ & 26 & 26.0 \\
\hline Number of years porters mostly stay in the south \\
\hline Variable & Frequency (n=100) & Percent (\%) \\
\hline Head about young women traveling for head porting \\
\hline No & 1 & 1.0 \\
\hline
\end{tabular}




\begin{tabular}{|c|c|c|}
\hline Yes & 99 & 99.0 \\
\hline \multicolumn{3}{|c|}{ Number of young women who move to the south } \\
\hline Mean $( \pm \mathrm{SD})$ & $116.71 \pm 67.96$ & \\
\hline$<50$ & 18 & 18.0 \\
\hline $50-99$ & 15 & 15.0 \\
\hline $100-199$ & 41 & 41.0 \\
\hline $200+$ & 26 & 26.0 \\
\hline \multicolumn{3}{|c|}{ Number of years porters mostly stay in the south } \\
\hline Variable & Frequency $(n=100)$ & Percent $(\%)$ \\
\hline \multicolumn{3}{|c|}{ Head about young women traveling for head porting } \\
\hline No & 1 & 1.0 \\
\hline Yes & 99 & 99.0 \\
\hline \multicolumn{3}{|c|}{ Number of young women who move to the south } \\
\hline Mean $( \pm \mathrm{SD})$ & $116.71 \pm 67.96$ & \\
\hline$<50$ & 18 & 18.0 \\
\hline $50-99$ & 15 & 15.0 \\
\hline $100-199$ & 41 & 41.0 \\
\hline $200+$ & 26 & 26.0 \\
\hline \multicolumn{3}{|c|}{ Number of years porters mostly stay in the south } \\
\hline Variable & Frequency $(n=100)$ & Percent $(\%)$ \\
\hline \multicolumn{3}{|c|}{ Head about young women traveling for head porting } \\
\hline No & 1 & 1.0 \\
\hline Yes & 99 & 99.0 \\
\hline \multicolumn{3}{|c|}{ Number of young women who move to the south } \\
\hline Mean $( \pm$ SD $)$ & $116.71 \pm 67.96$ & \\
\hline$<50$ & 18 & 18.0 \\
\hline $50-99$ & 15 & 15.0 \\
\hline $100-199$ & 41 & 41.0 \\
\hline $200+$ & 26 & 26.0 \\
\hline \multicolumn{3}{|c|}{ Number of years porters mostly stay in the south } \\
\hline Variable & Frequency $(n=100)$ & Percent $(\%)$ \\
\hline \multicolumn{3}{|c|}{ Head about young women traveling for head porting } \\
\hline No & 1 & 1.0 \\
\hline
\end{tabular}

Table 4. Health Status of Head Porters before and after Head Porting

\begin{tabular}{|l|l|l|}
\hline \multirow{2}{*}{ Variable } & \multicolumn{2}{|l|}{ Health status of female head porters } \\
\cline { 2 - 3 } & Before head porting & After head porting \\
\hline Healthy & $71 \%$ & $3 \%$ \\
\hline Not healthy & $1 \%$ & $97 \%$ \\
\hline Somehow healthy & $28 \%$ & 0 \\
\hline Total & $\mathbf{1 0 0} \%$ & $\mathbf{1 0 0}$ \\
\hline
\end{tabular}


Table 5. Impact of Head Porters on Native Communities

\begin{tabular}{|l|l|l|}
\hline Variable & Frequency $\mathbf{( n = 1 0 0 )}$ & Percent (\%) \\
\hline Adopting urban lifestyle & 12 & 12 \\
\hline Investment into business in the community & 24 & 24 \\
\hline There is financial support to families & 33 & 33 \\
\hline There is no positive impact & 34 & 34 \\
\hline Total & $\mathbf{1 0 0}$ & $\mathbf{1 0 0}$ \\
\hline
\end{tabular}

Table 6. Negative Effects of Head Porterage Returnees

\begin{tabular}{|l|l|l|}
\hline Variable & Frequency $(\mathbf{n = 1 0 0})$ & Percent $\mathbf{( \% )}$ \\
\hline Drug abuse & 10 & 10.0 \\
\hline Prostitution & 17 & 17.0 \\
\hline School dropout & 25 & 25.0 \\
\hline STD & 9 & 9.0 \\
\hline Stealing in the communities & 7 & 7.0 \\
\hline Teenage pregnancy & 31 & 31.0 \\
\hline Total & $\mathbf{1 0 0}$ & $\mathbf{1 0 0}$ \\
\hline
\end{tabular}

Table 7. Impact and Measures of Addressing the Movement of Young Women to the South

\begin{tabular}{|l|l|l|}
\hline Variable & Frequency (n=100) & Percent (\%) \\
\hline Positive impacts of movement on communities & 10.0 \\
\hline Adopting urban lifestyle & 10 & 22.0 \\
\hline Investment into business in the community & 22 & 33.0 \\
\hline Financial support to families & 33 & 35.0 \\
\hline No positive impact & 35 & \\
\hline Negative impact & 10 & 10.0 \\
\hline Drug abuse & 9 & 9.0 \\
\hline STD & 25 & 25.0 \\
\hline School drops out & 8 & 8.0 \\
\hline Stealing in the communities & 31 & 31.0 \\
\hline Teenage pregnancy & 17 & 17.0 \\
\hline Prostitution & 19 & 19.0 \\
\hline Measures to prevent young women from moving to the south & \\
\hline Providing vocational jobs & 10 & 10.0 \\
\hline Introducing them to petty trade & 13 & 13.0 \\
\hline Marrying out early & 30 & 30.0 \\
\hline Sending them to school & 28 & 28.0 \\
\hline Nothing & 78 & 74.0 \\
\hline Measures taken by government in addressing the situation & 17.0 \\
\hline Nothing & 74 & 9.0 \\
\hline School & 17 & 48.0 \\
\hline Vocational training centers & 9 & 41.0 \\
\hline Other measures the government could put in place \\
\hline Create jobs for the youth & 48 & \\
\hline Free education at the basic level & 11 & \\
\hline Establish vocational training institutes & 41 & \\
\hline & \multicolumn{2}{|l|}{} \\
\hline
\end{tabular}


Discussion

\section{Stakeholder Perception of Health Challenges Facing Female Head Porters in Kumasi}

According to the stakeholders, the majority of the head porters (38\%) had malaria followed by general body pains $(18.8 \%)$, typhoid fever $(15.2 \%)$, with the least recorded health challenge being wounds $(6.8 \%)$. Given the bad environmental surroundings of these respondents, it was not surprising that malaria was the major sickness confronting head porters. Most of the porters' experience symptoms of malaria at least twice every month.

The occurrence of malaria and other communicable diseases did not come as a surprise since the general environment of the female head porters was unkempt. The prevalence of malaria corroborates the assertion by [21] that communicable diseases can easily spread among female head porters due to congestion and poor environments. [13] also observed similar circumstances about the possibility of the spread of communicable diseases due to the congestion and unkempt environments of head porters.

\section{The Role of Stakeholders in Addressing the Migration of Females to Southern Ghana}

To appraise the factors that encouraged the migration and participation of females in head porting, stakeholders including parents, chiefs, assembly members, traditional leaders among others were interviewed at both the communities of origin and destination for these head porters. Out of the 100 sampled opinion leaders, almost all (99\%) of the respondents indicated that they have knowledge of the existence of head porting activities which is mainly undertaken by females. Only one of the respondents expressed a lack of knowledge on the existence of head porting.
Among the 100 stakeholders who participated in the study, about $78 \%$ expressed worries that peer influence was the major reason behind the migration of women and young girls and their subsequent involvement in head porting. This corroborates [15], who also finds that one of the menaces of female head porting is that many young ladies of schoolgoing age often cherish the lifestyle and the supposed self-reliance of returnee head porters. As a result, the other young girls are encouraged to engage in head porting. Also, about $9 \%$ of the respondents reasoned that female migration involving young girls was the result of poor parental care. This assertion is backed by the head porters as majority of them indicated that they migrated mainly because of economic reasons. [19] confirmed similar findings in their study of the conditions of head porters in Ghana. A respondent indicated that many parents neglect their role of providing basic needs for their children once they turn 14 and above years. Given girls' kind of care and needs within this age category, many of them resort to providing for their own needs independently through menial jobs. Since menial jobs are absent in the rural communities and can only be found in the larger cities, they migrate to the city. They, therefore, end up engaging in head porting activities because they may not have any skills that will place them in advantageous positions to secure a job.

It is common to find parents give their daughters in marriage to a man, which may be against the will of the girl. [12] also corroborates this finding that forced marriage is one of the reasons for engagement in head porting. To flee such unwanted marriages, they often move to the cities wherein search for life sustenance, end up in head porting. About $8 \%$ of the opinion leaders noted that young ladies 
who often migrate to the south did that as a result of forced marriage. The least $5 \%$ of the respondents indicated that the source of female migration was the pressure parents mount on their daughters to seek jobs and get employed. Figure 3 shows that employment $(27.0 \%)$ was the main economic reason for movement to the south among young girls. A majority, 78\%, also indicated that peer influence was the social reason that influenced the movement of head porters to the south (Table 3). No known association/agency was involved in assisting these young females into head porting.

Apart from the compelling social factors that lead to female migration, the opinion leaders also cited economic reasons that motivate some of the young girls to migrate. For instance, about $27 \%$ of the respondents noted that females often move to the south to seek employment. Also, 26\% noted that females who move to the south often search for money while $24 \%$ and $23 \%$ indicated that migration to seek for new trade and start a business for their parents were the respective reasons for this migration.

\section{Mechanism Employed by Female Head Porters in Addressing their Health Needs}

Opinion leaders were questioned on their knowledge about the return of these female migrants, their economic as well as the social influence these migrants have on their communities after a period of stay in Southern Ghana. Also, the views of stakeholders on measures to curb internal migration, especially of the young girls, were solicited. After the response, both from the opinion leaders and the head porters themselves proved a net disadvantage in their migration.

Figure 5 shows the response of the opinion leaders on the reasons that account for the return of female head porters to their various regions of origin after a period of head porterage. About $81 \%$ of the engaged stakeholders indicated that head porters return to their home regions after a period of stay in the south. The major reason accounting for the return of head porters was marriage $(54 \%)$, followed by funerals (18\%). Also, about $15 \%$ of the respondents noted that female head porters return to their native regions after they feel they had accumulated enough money to invest in business activity.

Many of the stakeholders (35\%) argued that the movement of head porters from northern Ghana to the south had no positive impact on the original communities of head porters upon return. However, $33 \%$ of the stakeholders indicated that it was a source of financial support to most families. About $10 \%$ of the respondents indicated that the head porters only come back, portraying an urban lifestyle with nothing tangible to offer. Opinion leaders were asked to rate the health status of head porters prior to and after their return from southern Ghana. About $71 \%$ rated the health conditions of the young ladies who migrate to the south for head porting as being healthy, as shown in Table 4. However, after their return, about $97 \%$ of the opinion leaders noted that the head porters come back home with various types of sicknesses. Table 4 presents the number of opinion leaders who answered in affirmative on the health deteriorations of head porters. Interestingly, $31 \%$ of the opinion leaders indicated that teenage pregnancy was a major negative impact on these communities. The rate of school dropout, 25\%, was also cited as a major negative influence of the head porter returnees. This is due to peer influence which motivates several young girls of school-going age to abandon their school for head porting activities in town. The negative effects of head porter returnees are outlined in Table 8 .

\section{Recommendations to Address Female Movement to the South}

Opinion leaders, during the interview, indicated that lack of jobs in the Northing part of Ghana, high school's fees, and poverty were the major challenges that often lead to the North-South migration. They noted the 
inadequate measures of the government to provide an enabling environment in this part of the country to retain these young once in order to reduce the movement. Out of the 100 sampled opinion leaders, the majority, about $74 \%$, indicated that the government had done nothing to reduce the movement of these young females to the south. On the contrary, $17 \%$ indicated that 'School for Life' was one of the interventions to engage the young ones. Also, $9 \%$ of the respondents also indicated that the establishment of Vocational Training Centers could reduce the movement (Table 7).

To curb the movement of young women to the south for head porting activities, nearly half, $48 \%$ of the stakeholders noted that creating jobs in the Northern part of Ghana was the major intervention by the government to effectively reduce the movement. Also, $41 \%$ of the respondents recommended the establishment of vocational training centres to engage those young ones to prevent the movement. Also, $11 \%$ of the respondents, however, believed that making the basic schools free for every child could increase enrollment and retention rates, which could subsequently discourage the movement. The recommended measures of curbing female migration to the south are shown in Table 7.

\section{Competing interests}

The authors declare that they have no competing interest.

\section{References}

[1] ILO. (2004). World employment report 2004-05. Employment, productivity, and poverty reduction (includes CD-ROM). Retrieved from http://www.ilo.org/global/publications/ilobookstore/orderonline/books/WCMS_PUBL_9221148130_EN/lang-en/index.htm.

[2] Shamsu-Deen, Z., \& Adadow, Y. (2019). Healthseeking behaviour among migrant female head porters in the City of Accra, Ghana. Ghana Journal

\section{Conclusion}

While female head porting is a source of income for the people who engage in head porting, the health challenges and other social vices associated with it make it disadvantageous to society. The study found that financial crises, peer pressure, and lack of parental care and control accounted for the engagement of young girls in head porting business. Even though stakeholders suggest skills training, setting up of entrepreneurial schools, and governmental interventions such as job creation in controlling the increasing rate of young girls engaged in head porting, parental care, and control, family life education must take immediate measures to control the menace.

\section{Funding}

No external funding was received for this study. The researchers themselves covered all cost related to this research.

\section{Acknowledgement}

The author thanks the almighty God for the gift of strength to study. The author also extends appreciation to his family, friends and the school's authorities for the guidance and intellectual discourse enjoyed. Lastly, the author expresses sincere gratitude to the supervisors and anonymous reviewers who contributed to shaping this work.

of Development Studies, 16(2), 138-156-156. https://doi.org/10.4314/gjds.v16i2.7.

[3] Tufeiru, A. (2014). The Nexus of Female Capital and North-South Labor Migration in Ghana: A Potential Remedy from Microfinance. Journal of Developing Societies 30(1), 91-114. https://doi.org/10.1177/0169796X13504680.

[4] Owusu-Ansah, J. K., \& Addai, M. (2016). Coping with life in a squatter settlement: The case of migrant women in Kumasi, Ghana. Journal of $\begin{array}{lll}\text { Science } \quad \text { and } & \text { Technology, }\end{array}$ 
https://webapps.knust.edu.gh/just/index.php?journal $=$ just $\&$ page $=$ article $\&$ op $=v i e w \& p a t h \% 5 B \% 5 d=1426$. [5] Owusu, A. (2012). The Living Conditions of Female Head Porters in the Kumasi Metropolis, Ghana. Retrieved July 31, 2017, from Research Gate website: https://www.researchgate.net.

[6] Opare, J. A. (2003). Kayayei: The women head porters of southern Ghana. Journal of Social Development in Africa, 18(2). https://doi.org/10.4314/jsda.v18i2.23825.

[7] Hashim, I. (2007). Independent Child Migration and Education in Ghana. Development and Change, $38(5)$, 911-931. https://doi.org/10.1111/j.14677660.2007.00439.x.

[8] Kwankye, S. O., Anarfi, J. K., Tagoe, C. A., \& Castaldo, A. (2007). Coping Strategies of Independent Child Migrants from Northern Ghana to Southern

Cities

(Available):/publication/237502608_Coping_Strateg ies_of_Independent_Child_Migrants_from_Norther n_Ghana_to_Southern_Cities.

[9] Otieku, E., Ackah, C. G., \& Forkuor, D. (2017). Motivations, income determinants, and livelihood vulnerability of female teenage head porters in Kasoa, Ghana. International Journal of Social Economics, 44(12), 2396-2408. https://doi.org/10.1108/IJSE-10-2016-0286.

[10] Nyarko, S. H., \& Tahiru, A. M. (2018). Harsh Working Conditions and Poor Eating Habits: Health-Related Concerns of Female Head Porters (Kayayei) in the Mallam Atta Market, Accra, Ghana. BioMed Research International, 2018, 1-7. https://doi.org/10.1155/2018/6201837.

[11] Agarwal, S., Attah, M., Apt, N., Grieco, M., Kwakye, E. A., \& Turner, J. (1997). Bearing the weight: The kayayoo, Ghana's working girl child. International Social Work, 40(3), 245-263. https://doi.org/10.1177/002087289704000302.

[12] Azumah, F. D. \& Onzaberrugu J. N. (2018). The Lifestyle of female head porters: the single mother and her coping strategies at Aboabo, Kumasi. International Journal of Innovation Education and Research 6(2).

[13] Owusu, L. \& Yeboah, T. (2018). Living conditions and social determinants of healthcare inequalities affecting female migrants in Ghana. GeoJournal.

[14]Boateng, S., Amoako, P., Poku, A. A., Baabereyir, A., \& Gyasi, R. M. (2017). Migrant female head porters' enrolment in and utilization and renewal of the National Health Insurance Scheme in Kumasi, Ghana.

[15]Bessey, F. O. (2015). The Woes of the Returnee Female Migrant: Case of Kayayei from Northern Ghana. Developing Country Studies, 5(6), 168-172. Retrieved from

http://www.iiste.org/Journals/index.php/DCS/article/ view/2098.

[16] Shamsu-Deen, Z. (2013). Migration and Health Nexus: A Case of Female Porters (Kayayei) in Accra, Ghana. Research on Humanities and Social Sciences, 3(3), 103-109.

http://www.iiste.org/Journals/index.php/RHSS/articl e/view/4936

[17] Owusu, G., Agyei-Mensah, S. and Lund, R. (2008). Slums of hope and slums of despair: Mobility and livelihoods in Nima, Accra, Norsk Geografisk Tidsskrift, 62:180-190.

[18] Boakye-Yiadom, L., \& Mckay, A. (2006). Migration between Ghana's Rural and Urban Areas: The Impact on Migrants Welfare (PDF Download Available). Retrieved August 3, 2017, from Research Gate website: https://www.researchgate.net/publication/228393018 _Migration_between_Ghana's_Rural_and_Urban_A reas_The_Impact_on_Migrants_Welfare.

[19]Awumbila, M., \& Ardayfio-Schandorf, E. (2008). Gendered poverty, migration and livelihood strategies of female porters in Accra, Ghana. Norwegian Journal of Geography, 62(3), 171-179. https://doi.org/10.1080/00291950802335772.

[20] Yeboah, M. (2008). Gender and livelihoods: Mapping the economic strategies of porters in Accra, Ghana. Retrieved July 31, 2017, from http://pqdtopen.proquest.com/doc/304446957.html? $\mathrm{FMT}=\mathrm{ABS}$.

[21]Wilson, A., \& Mittelmark, M. B. (2013). Resources for Adjusting Well to Work Migration: Women from Northern Ghana Working in Head Porterage in Greater Accra. Africa Today, 59(4), 24 
38.

https://muse.jhu.edu/article/511476.

[22] Wilson, A. (2012). Resources for Thriving among Female porters in Accra. A Qualitative study of Migrants from Northern Ghana to Greater Accra Region. A Salutogenic Approach. Retrieved from https://bora.uib.no/handle/1956/5879.

[23] Jenkins, E. K., Slemon, A., Haines-saah, R. J., \& Oliffe, J. (2018). A Guide to Multisite Qualitative Analysis. Qualitative Health Research, 28(12), 1969-1977. https://doi.org/10.1177/1049732318786703.

[24] Guest, B. G., Macqueen, K. M., \& Namey, E. E. (2014). Integrating Qualitative and Quantitative Data. In Applied Thematic Analysis (pp. 187-216). Thousand Oaks: SAGE Publications, Inc.

[25] Guest, B. G., Namey, E. E., \& Mitchell, M. L. (2017). Sampling in Qualitative Research. In Collecting Qualitative Data: A Field Manual for Applied Research (pp. 41-74). 55 City Road: SAGE Publications, Ltd. 